PJI was in receipt of a grant from Birthright, Royal College of Obstetricians and Gynaecologists, which supported this work.

\section{References}

1 National Research Council. Recommended dietary allowances. 9th ed. Washington: National Academy of Sciences, 1980

2 Whitehead RG, Paul AA, Black AE, Wiles SJ. Recommended dietary amounts of energy for pregnancy and lactation in the United Kingdom. In: Torun B, Young VR, Rang WM, eds. Protein energy requirements of developing countries: evaluation of new data. Tokyo: United Nation University, 1981:259-65.

3 Butte NF, Garza C, Stuff JE, Smith EO, Bichos BJ. Effect of maternal diet and body composition on lactational performance. Am f Clin Nutr 1984;39:296-306.

4 Schutz Y, Lechtig A, Bradfield RB. Energy expenditures and food intakes of lactating women in Guatemala. Am J Clin Nutr 1980;33:892-902.

5 Durnin JVGA. Food consumption and energy balance during pregnancy and lactation in New Guinea. In: Aebi HG, Whitehead RG, eds. Maternal nutrition during pregnancy and lactation. Berne: Hans Huber, 1980:86-95.

6 Prentice AM, Whitehead RG, Roberts SB, Paul AA. Long-term energy balance in child-bearing Gambian women. Am $\mathcal{J}$ Clin Nutr 1981;34:2790-9.

7 Durnin JVGA, Womersley J. Body fat assessed from total body density and its estimation from skinfold thickness: measurements on 481 men and women aged from 16 to 72 years. Br $\mathcal{F}$ Nutr 1974;32:77-97.

8 McCance RA, Widdowson EM, Paul AA, Southgate DAT. McCance and Widdowson's the composition of foods. London: HMSO, 1978.

9 Weir JBD. New methods for calculating metabolic rate with special reference to protein metabolism. I Physiol 1949;109: 1.

10 Royal College of Physicians of London. Report: obesity. I R Coll Physicians Lond 1983;17:4-6.

11 Metropolitan Life Insurance Company. Morbidity among overweight men and women. Statistical Bulletin 1960;41: February:6.

12 Jung RT, Shetty PS, James WPT, Barrand MA, Callingham BA. Reduced thermogenesis in obesity. Nature 1979;279:322-3.
13 Trinder P. Determination of blood glucose using an oxidase-peroxidase system with a noncarcinogenic chromogen. $f$ Clin Pathol 1969;23:158-61.

14 Chromy V, Bergel J, Voznicek J, Kromholzova L, Musil J. Assay of serum free fatty acids by extraction-photometric procedure. Clin Chim Acta 1977;80:327-32

15 Howie PW, McNeilly AS, McArdle T, Smart L, Houston M. The relationship between suckling induced prolactin response and lactogenesis. $\mathcal{F}$ Clin Endocrinol Metab 1980;50:670-3.

16 World Health Organisation/Food and Agriculture Organisation. Energy and protein requirements. WHO Tech Rep Ser 1973;522.

17 Whitehead RG, Paul AA, Cole TJ. How much milk do babies need? Acta Paediatr Scand [Suppl] 1982;299:43-50.

18 Trayhurn P, Douglas JB, McGuckin MM. Brown adipose tissue thermogenesis is 'suppressed' during lactation in mice. Nature 1982;298:59-60.

19 Agius L, Rolls BJ, Rowe EA, Williamson DH. Increased lipogenesis in brown adipose tissue of lactating rats fed a cafeteria diet. FEBS Lett 1981;123:45-8.

20 Trayhurn P. Decreased capacity for non-shivering thermogenesis during lactation in mice. Pflugers Arch 1983;398:264-5.

21 Shetty PS, Jung RT, James WPT, Barrand MA, Callingham BA. Post-prandial thermogenesis in obesity. Clin Sci 1981;60:519-25.

22 Cunningham $S$, Leslie $P$, Hopwood $D$, et al. The characterisation and energetic potential of brown adipose tissue in man. Clin Sci 1985;69:343-8.

23 Astrup A, Bulow J, Madsen J, Christensen NJ. Contribution of BAT and skeletal muscle to thermogenesis induced by ephedrine in man. Am f Physiol 1985;248:E507-15.

24 Golay A, Schutz Y, Meyer HU, et al. Glucose induced thermogenesis in non-diabetic and diabetic obese subjects. Diabetes 1982;31:1023-8.

25 Felig P. Insulin is the mediator of feeding-related thermogenesis: insulin resistance and/or deficiency results in a thermogenic defect which contributes to the pathogenesis of obesity. Clin Physiol 1984;4:267-73.

26 Cowie AT, Forsyth IA, Hart IC. Hormonal control of lactation. Berlin: Springer-Verlag, 1980

27 Flint DJ. Role of insulin receptors in nutrient partitioning between mammary gland and adipose tissue. Biochem Soc Trans 1985;13:828-9.

28 Bazelmans J, Nestel PJ, O'Dea K, Esler MD. Blunted norepinephrine responsiveness to changing energy states in obese subjects. Metabolism 1985;34:154-60

29 Berry MN, Clark DG, Grivell AR, Wallace PG. The contribution of hepatic metabolism to die induced thermogenesis. Metabolism 1985;34:141-7.

(Accepted 26 November 1985 )

\title{
Long term respiratory sequelae of whooping cough in a nationally representative sample
}

\author{
NICKY BRITTEN, JANE WADSWORTH
}

\begin{abstract}
The long term respiratory consequences of whooping cough in childhood were sought among members of the National Survey of Health and Development. Peak expiratory flow rate was measured when the survey members were 36 years old and seven respiratory symptoms were reported at the same time. Peak expiratory flow rate was slightly reduced in those who had had whooping cough as a child, and this difference became non-significant when other factors were taken into account. Unexpectedly, chronic cough was significantly less likely to be reported by those who had had whooping cough, and this difference remained significant only among men after other factors had been taken into account.

This study failed to show a long term detrimental effect of whooping cough on the respiratory system.
\end{abstract}

\section{Introduction}

Up to the mid-1950s whooping cough was a common infectious disease which a child was considered fortunate to escape. Notifica-

MRC National Survey of Health and Development, Department of Epidemiology and Community Medicine, University of Bristol, Bristol BS8 2PR

NICKY BRITTEN, MA, MSC, research associate

Academic Department of Community Medicine, St Mary's Hospital Medical School, London W2

JANE WADSWORTH, BSC, MSC, lecturer in medical statistics

Correspondence to: Ms Britten. tions in the late 1940 s were of the order of 100000 cases a year, compared with less than half that number today. Before the introduction of routine vaccination in 1957 it is likely that almost all the population was infected by adulthood'; nevertheless, by no means all adults were conscious of having had whooping cough as a child, so that it was clearly an infection which could pass unrecognised if the classical whoop was absent. A severe case of whooping cough in a young child may be a terrifying, unforgettable, and protracted experience for the parents with the possibility of serious sequelae for the child. James et al in 1956 reported whooping cough as the most likely cause of pulmonary collapse in children. ${ }^{2}$ In 1946-7 the case fatality rate of notified whooping cough was roughly one in 100, declining to about one in 500 in 1950-1 and to one in 3000 today.

Johnston et al and the Swansea Research Unit of the Royal College of General Practitioners reported on the short term pulmonary consequences of whooping cough ${ }^{34}$ Both studies detected an increased prevalence of respiratory symptoms in primary school children who had had whooping cough. Contrary to the findings of Johnston et al, the Swansea Research Unit found a small but significant reduction in lung function up to the age of 7 , but not thereafter. We have analysed the long term consequences of whooping cough.

\section{Subjects and methods}

The Medical Research Council's National Survey of Health and Development is a longitudinal study of 5362 women and men who were born in the first week of March 1946 in England, Scotland, and Wales. ${ }^{5}$ The original population was sampled to include all the children of agricultural and nonmanual workers and a one in four sample of children of manual workers. Population estimates may be obtained by statistical reweighting of the data. 
The survey members were contacted at intervals of not more than two years until the age of 26 and at five year intervals subsequently. The data of interest in this study are those on whooping cough in children, peak expiratory flow rate measured at age 36 , and respiratory symptoms reported at the same age. The child's mother was asked about whooping cough on six occasions between the ages of 2 and 11 by the health visitor or the school nurse. She was also asked in 1952, when the child was 6 years old, if he or she had ever been immunised against whooping cough.

Peak expiratory flow rate was measured using a mini Wright peak flow meter, and all the instruments were calibrated to a single standard. Five readings were taken, the mean of the last three being used in this paper. Questions about respiratory symptoms were those approved by the MRC Committee on the Aetiology of Chronic Bronchitis. ${ }^{6}$

The other variables drawn from the data bank for use in this study were lower respiratory infection and air pollution in childhood, father's social class, and smoking habits at age 36 . Data on lower respiratory illness before the age of 2 years included bronchitis, bronchopneumonia, and pneumonia and were collected by the health visitors who interviewed the mothers. Levels of air pollution were calculated for each survey member according to place of residence up to the age of $11 .^{7}$ An index of exposure to air pollution was obtained by summing the levels measured on eight occasions between 1946 and 1957. Father's social class was based on his occupation in 1950 when the child was 4 and classified according to the definitions of the Office of Population Censuses and Surveys. At the age of 36 survey members were asked whether or not they smoked cigarettes.

The relations between peak expiratory flow rate and whooping cough in childhood were explored using multiple linear regression ${ }^{8}$ and between chronic cough and whooping cough using logistic regression. ${ }^{9}$

\section{Results}

Table I shows the age at which the survey members were reported to have had whooping cough; half the population had had whooping cough by the age of 5 . The last occasion on which the mother was asked about whooping cough was in early 1957, just before the child's 11 th birthday. By that age $57 \cdot 4 \%$ of the population had had whooping cough. Probably some children would have had whooping cough beyond 11 years of age, but figures based on official notifications ${ }^{1}$ for the period do not suggest that the number would have been large.

The incidence of whooping cough in this cohort was much greater than the official notification rate for the corresponding years (table II). Though the incidence rates were for slightly different age groups, there were striking differences between the national survey figures and official notifications.

Whooping cough was more common in girls, children with other chest illnesses before the age of 2 , and children of non-manual workers (table III).

TABLE I-Incidence of whooping cough in National Survey of Health and Development by age and sex

\begin{tabular}{lrrrc}
\hline Age (years) & Boys & Girls & Total & Cumulative \% \\
\hline$<2$ & 294 & 309 & 603 & $14 \cdot 3$ \\
2 & 166 & 197 & 363 & $22 \cdot 9$ \\
3 & 150 & 153 & 303 & $30 \cdot 1$ \\
4 & 180 & 208 & 388 & $39 \cdot 3$ \\
5 & 221 & 223 & 444 & $49 \cdot 8$ \\
6 & 77 & 63 & 140 & $53 \cdot 1$ \\
7 & 52 & 50 & 102 & $55 \cdot 5$ \\
8 & 19 & 25 & 44 & $56 \cdot 5$ \\
9 & 11 & 18 & 29 & $57 \cdot 2$ \\
10 & 3 & 7 & 10 & $57 \cdot 4$ \\
\hline No whooping cough & 1027 & 772 & 1799 & \\
\hline Total & 2200 & 2025 & 4225 & \\
\hline
\end{tabular}

TABLE II-Incidence of whooping cough in National Survey of Health and Development compared with official notifications in England and Wales

\begin{tabular}{|c|c|c|c|}
\hline \multicolumn{2}{|c|}{ National Survey } & \multicolumn{2}{|c|}{ Notifications in England and Wales } \\
\hline Age (years) & Rate $/ 1000^{\star}$ & Age (years) & Rate $/ 1000$ \\
\hline$<2$ & $145 \cdot 7$ & $<1(1946)$ & $13 \cdot 5$ \\
\hline $2-4$ & $249 \cdot 6$ & $1-4(1947-50)$ & $25 \cdot 7$ \\
\hline $5-9$ & $165 \cdot 5$ & $5-9(1951-5)$ & $12 \cdot 4$ \\
\hline
\end{tabular}

^ Figures reweighted to original population.
TABLE III-Proportion of survey members who had whooping cough by various factors

\begin{tabular}{|c|c|c|c|}
\hline & $\begin{array}{c}\% \text { With } \\
\text { whooping cough }\end{array}$ & No & Significance \\
\hline $\begin{array}{l}\text { Girls } \\
\text { Boys }\end{array}$ & $\begin{array}{l}62 \cdot 3 \\
54 \cdot 3\end{array}$ & $\left.\begin{array}{l}1077 \\
1082\end{array}\right\}$ & $\mathrm{p}<0.05$ \\
\hline $\begin{array}{l}\text { Chest illnesses before age 2: } \\
\text { None } \\
\text { One or more }\end{array}$ & $\begin{array}{l}56 \cdot 7 \\
61 \cdot 6\end{array}$ & $\left.\begin{array}{r}2093 \\
771\end{array}\right\}$ & $\mathrm{p}<0.05$ \\
\hline $\begin{array}{l}\text { Social class: } \\
\text { Non-manual } \\
\text { Manual }\end{array}$ & $\begin{array}{l}58 \cdot 4 \\
56 \cdot 2\end{array}$ & $\left.\begin{array}{l}1607 \\
2416\end{array}\right\}$ & $\mathrm{p}<0.05$ \\
\hline $\begin{array}{l}\text { Smoking: } \\
\text { At age } 36 \\
\text { In past } \\
\text { Never }\end{array}$ & $\begin{array}{l}55 \cdot 4 \\
62 \cdot 0 \\
57 \cdot 3\end{array}$ & $\left.\begin{array}{l}821 \\
700 \\
607\end{array}\right\}$ & $\mathrm{p}<0.05$ \\
\hline
\end{tabular}

The association between whooping cough in childhood and adult respiratory illness was examined using seven respiratory symptoms and the peak expiratory flow rates. The symptoms were winter morning cough, cough day or night in winter, winter morning phlegm, phlegm day or night in winter, cough and phlegm for three weeks or more, wheezy chest ever, and chest illness in the past three years. All were elicited using questions from the standard MRC questionnaire. ${ }^{6}$ There was no significant association between whooping cough and any of the respiratory symptoms except chronic cough, and, surprisingly, those who had had whooping cough reported a lower prevalence of chronic cough than those who had not had whooping cough. Table IV shows the mean peak flow rates and incidence of chronic cough for various factors which may be important in interpreting the relation between whooping cough and these respiratory indices.

TABLE IV-Mean peak flow rate and incidence of chronic cough at age 36 by various factors

\begin{tabular}{|c|c|c|c|c|c|c|}
\hline & $\begin{array}{c}\text { Mean peak } \\
\text { flow rate } \\
(\mathrm{l} / \mathrm{min})\end{array}$ & No & Significance & $\begin{array}{l}\text { \% Incidence } \\
\text { of chronic } \\
\text { cough }\end{array}$ & No & Significance \\
\hline Overall & $482 \cdot 8$ & 3276 & & $8 \cdot 3$ & 3282 & \\
\hline $\begin{array}{l}\text { Whooping cough } \\
\text { No } \\
\text { Yes }\end{array}$ & $\begin{array}{l}488 \cdot 7 \\
478 \cdot 0\end{array}$ & $\left.\begin{array}{l}1240 \\
1695\end{array}\right\}$ & $\mathrm{p}<0.01$ & $\begin{array}{r}10 \cdot 4 \\
7 \cdot 2\end{array}$ & $\left.\begin{array}{l}1247 \\
1690\end{array}\right\}$ & $p<0.01$ \\
\hline $\begin{array}{l}\text { Chest illnesses b } \\
\text { None } \\
\text { One or more }\end{array}$ & $\begin{aligned} & \text { age } 2: \\
& 483 \cdot 7 \\
& 478 \cdot 8\end{aligned}$ & $\left.\begin{array}{r}2298 \\
778\end{array}\right\}$ & NS & $\begin{array}{r}7 \cdot 3 \\
11 \cdot 7\end{array}$ & $\left.\begin{array}{r}2301 \\
781\end{array}\right\}$ & $\mathrm{p}<0.001$ \\
\hline $\begin{array}{l}\text { Pollution index: } \\
\text { Low } \\
\text { High }\end{array}$ & $\begin{array}{l}477 \cdot 9 \\
486 \cdot 5\end{array}$ & $\left.\begin{array}{l}1380 \\
1402\end{array}\right\}$ & $\mathrm{p}<0.05$ & $\begin{array}{l}8 \cdot 2 \\
8 \cdot 4\end{array}$ & $\left.\begin{array}{l}1384 \\
1399\end{array}\right\}$ & NS \\
\hline $\begin{array}{l}\text { Father's social cl } \\
\text { Non-manual } \\
\text { Manual }\end{array}$ & $\begin{array}{l}495 \cdot 0 \\
475 \cdot 1\end{array}$ & $\left.\begin{array}{l}1252 \\
1766\end{array}\right\}$ & $\mathrm{p}<0.001$ & $\begin{array}{r}6 \cdot 2 \\
10 \cdot 1\end{array}$ & $\left.\begin{array}{l}1254 \\
1769\end{array}\right\}$ & $\mathrm{p}<0.001$ \\
\hline $\begin{array}{l}\text { Smoking at age } 3 \\
\text { Non-smoker } \\
\text { Smoker }\end{array}$ & $\begin{array}{l}486 \cdot 6 \\
475 \cdot 6\end{array}$ & $\left.\begin{array}{l}2166 \\
1108\end{array}\right\}$ & $\mathrm{p}<0.01$ & $\begin{array}{r}4 \cdot 2 \\
16 \cdot 4\end{array}$ & $\left.\begin{array}{l}2168 \\
1112\end{array}\right\}$ & $\mathrm{p}<0.001$ \\
\hline $\begin{array}{l}\text { Sex: } \\
\text { Men } \\
\text { Women }\end{array}$ & $\begin{array}{l}554 \cdot 4 \\
411.9\end{array}$ & $\left.\begin{array}{l}1629 \\
1647\end{array}\right\}$ & $<0.001$ & $\begin{array}{l}8 \cdot 8 \\
7 \cdot 8\end{array}$ & $\left.\begin{array}{l}1635 \\
1647\end{array}\right\}$ & NS \\
\hline
\end{tabular}

Clearly there are many factors which influence peak expiratory flow rate, and among the most important is height. ${ }^{10}$ Peak expiratory flow rates were divided by height (measured to the nearest $0.5 \mathrm{~cm}$ ) before multiple linear regression was used to investigate the relation between lung function and whooping cough taking many other factors into account. When sex, father's social class, current smoking, pollution index, and lower respiratory illness before age 2 were taken into account there was no significant difference in peak expiratory flow rate between people who had had whooping cough and those who had not. By far the largest difference was between men and women, and by analysing them separately different models were obtained, but whooping cough remained non-significant (table V).

The proportion of people reporting chronic cough was analysed using a log linear model which included the same factors as in the linear regression analysis. The negative association with whooping cough remained a significant factor even after current and past smoking habits and lower respiratory illness had been taken into account. When men and women were considered separately different models emerged and whooping cough became less significant for men and non-significant for women (table VI).

These analyses assume that whooping cough affects respiratory function in such a way that a reduction in peak expiratory flow rate proportional to the severity of whooping cough would be expected, and such a reduction was not apparent in our data. Possibly, however, there is a threshold in the severity 
of whooping cough beyond which patients may suffer long term damage, all other patients recovering completely. No direct measure of severity of whooping cough was available in this study, though two possible indirect measures-hospital admission and duration of symptoms-were recorded. Comparing the group of survey members with height adjusted peak expiratory flow rate less than 2 standard deviations below the mean with those for whom it was greater than 2 standard deviations above the mean, there was no significant difference in duration of whooping cough symptoms. Nineteen survey members were admitted to hospital with whooping cough. Two of these died of the disease and 11 of the remainder incidence rates reported in this study were some 10 times higher than the official notification rates. This may have been due to overnotification by parents, but other workers believe that parents are very good at diagnosing whooping cough as they are likely to be present when the child whoops. " Our data reinforce the belief that whooping cough was undernotified in the first five years of the survey members' lives.

Four of the original population died of whooping cough in their first year and one at age 3 , and of the survivors most were girls,

\begin{tabular}{|c|c|c|c|c|c|c|}
\hline & \multicolumn{3}{|c|}{ Men } & \multicolumn{3}{|c|}{ Women } \\
\hline & Mean & $\begin{array}{l}\text { Difference as \% of } \\
\text { residual } \\
\text { standard error }\end{array}$ & Significance & Mean & $\begin{array}{l}\text { Difference as \% of } \\
\text { residual } \\
\text { standard error }\end{array}$ & Significance \\
\hline $\begin{array}{l}\text { Father's social class: } \\
\text { Non-manual } \\
\text { Manual }\end{array}$ & $\left.\begin{array}{l}0.3195 \\
0.3155\end{array}\right\}$ & $9 \cdot 4$ & NS & $\left.\begin{array}{l}0 \cdot 2582 \\
0 \cdot 2485\end{array}\right\}$ & $24 \cdot 0$ & $\mathrm{p}<0.001$ \\
\hline $\begin{array}{l}\text { Chest illnesses before age } \\
\text { None } \\
\text { One or more }\end{array}$ & $\left.\begin{array}{l}0 \cdot 3182 \\
0.3140\end{array}\right\}$ & $9 \cdot 8$ & NS & $\left.\begin{array}{l}0 \cdot 2531 \\
0 \cdot 2504\end{array}\right\}$ & $6 \cdot 7$ & NS \\
\hline $\begin{array}{l}\text { Pollution index: } \\
\text { Low } \\
\text { High }\end{array}$ & $\left.\begin{array}{l}0.3150 \\
0.3194\end{array}\right\}$ & $10 \cdot 3$ & NS & $\left.\begin{array}{l}0.2496 \\
0.2553\end{array}\right\}$ & $14 \cdot 1$ & $\mathrm{p}<0.02$ \\
\hline $\begin{array}{l}\text { Smoking at age } 36: \\
\text { Non-smoker } \\
\text { Smoker }\end{array}$ & $\left.\begin{array}{l}0.3195 \\
0.3125\end{array}\right\}$ & $16 \cdot 4$ & $\mathrm{p}<0.05$ & $\left.\begin{array}{l}0.2534 \\
0.2505\end{array}\right\}$ & $7 \cdot 2$ & NS \\
\hline $\begin{array}{l}\text { Whooping cough: } \\
\text { No } \\
\text { Yes }\end{array}$ & $\left.\begin{array}{l}0.3153 \\
0.3188\end{array}\right\}$ & $8 \cdot 2$ & NS & $\left.\begin{array}{l}0 \cdot 2528 \\
0 \cdot 2522\end{array}\right\}$ & $1 \cdot 5$ & NS \\
\hline $\begin{array}{l}\text { Overall mean } \\
\text { Residual standard error }\end{array}$ & $\begin{array}{l}0.3172 \\
0.04267\end{array}$ & & & $\begin{array}{l}0 \cdot 2524 \\
0 \cdot 04049\end{array}$ & & \\
\hline
\end{tabular}

TABLE VI-Raw and adjusted percentages of people who reported chronic cough

\begin{tabular}{|c|c|c|c|c|}
\hline & \multicolumn{2}{|c|}{ Men } & \multicolumn{2}{|c|}{ Women } \\
\hline & Raw & Adjusted ${ }^{\star}$ & Raw & Adjusted ${ }^{\star}$ \\
\hline $\begin{array}{l}\text { Father's social class: } \\
\text { Non-manual } \\
\text { Manual } \\
\text { Significance }\end{array}$ & $\begin{array}{l}5 \cdot 98 \\
9 \cdot 29\end{array}$ & $\begin{array}{l}6 \cdot 81 \\
8 \cdot 73 \\
\text { NS }\end{array}$ & $\begin{array}{r}5 \cdot 74 \\
10.01\end{array}$ & $\begin{array}{l}7 \cdot 19 \\
9 \cdot 31 \\
\text { NS }\end{array}$ \\
\hline $\begin{array}{l}\text { Chest illnesses before } \\
\text { None } \\
\text { One or more } \\
\text { Significance }\end{array}$ & $\begin{array}{l}\text { 2: } \\
7 \cdot 35 \\
9 \cdot 76\end{array}$ & $\begin{array}{c}7 \cdot 27 \\
10 \cdot 00 \\
\text { NS }\end{array}$ & $\begin{array}{r}7 \cdot 22 \\
12 \cdot 59\end{array}$ & $\begin{array}{c}7.32 \\
11.91 \\
p<0.05\end{array}$ \\
\hline $\begin{array}{l}\text { Smoking: } \\
\text { Never } \\
\text { Past } \\
\text { Present (at age 36) } \\
\text { Significance }\end{array}$ & $\begin{array}{r}4 \cdot 08 \\
4 \cdot 66 \\
15 \cdot 13\end{array}$ & $\begin{array}{c}4.23 \\
4.91 \\
14 \cdot 73 \\
\mathrm{p}<0.001\end{array}$ & $\begin{array}{r}4 \cdot 48 \\
3 \cdot 48 \\
17 \cdot 49\end{array}$ & $\begin{array}{c}4.46 \\
3.85 \\
17 \cdot 15 \\
p<0.001\end{array}$ \\
\hline $\begin{array}{l}\text { Whooping cough: } \\
\text { No } \\
\text { Yes } \\
\text { Significance }\end{array}$ & $\begin{array}{r}10 \cdot 75 \\
5.49\end{array}$ & $\begin{array}{c}10.66 \\
5.57 \\
p<0.01\end{array}$ & $\begin{array}{l}9 \cdot 17 \\
8 \cdot 02\end{array}$ & $\begin{array}{l}9 \cdot 59 \\
7 \cdot 77 \\
\text { NS }\end{array}$ \\
\hline Total & & & & \\
\hline
\end{tabular}

^ Rates adjusted for other factors in model.

had peak expiratory flow rates recorded at age 36 . The mean height adjusted peak expiratory flow rate was not reduced in the five men and it was reduced by half a standard deviation in the six women, a non-significant difference.

\section{Discussion}

Half the study population was reported to have had whooping cough by the age of 5 (by 1950), and the five years 1946-50 were at the beginning of one of the last big epidemics before the introduction of immunisation. In England and Wales the number of whooping cough notifications ranged between 95000 and $160000 \mathrm{a}$ year, but at the same time the case fatality rate was falling fast. Fine and Clarkson have shown that notification rates grossly underestimate infection rates and, to some extent, disease rates, ${ }^{1}$ and the which has been found in other studies. Reweighting these figures to the total population gives an expected 10 children who would have died. Children of manual workers got whooping cough at a younger age, but overall a larger proportion of children whose fathers were in non-manual occupations were reported to have had whooping cough than of those whose fathers had manual occupations. This was an unexpected finding ${ }^{34}$ but may have been the result of more sensitive reporting by better educated parents.

The small difference in peak expiratory flow rates associated with whooping cough was related predominantly to sex. By analysing the data separately for men and women whooping cough became nonsignificant, and we deduce from this that the apparent association between whooping cough and reduced peak flow rate was an artefact of the larger proportion of girls who contracted the disease.

We expected that those with low peak flow rates would have had a longer duration of whooping cough than those with high peak flow rates or that those who had been admitted to hospital for whooping cough would show a significant reduction in lung function. Using these two indirect measures of severity of whooping cough, hospital admission and duration of symptoms, no evidence was found for reduced lung function in the most severe cases.

Other reports from this study have shown a relation between respiratory illness in the first two years of life and chronic cough in early adulthood. ${ }^{12}{ }^{13}$ As whooping cough was commonly implicated in cases of collapsed lung a relation with chronic cough might also be expected. The negative association between chronic cough and whooping cough was hard to interpret.

Studies of young children have shown that those who had whooping cough were more susceptible to other respiratory infections, ${ }^{34}$ and our data bear this out when considering lower respiratory infections in the first two years; but it seems surprising that at age 36 those men who had whooping cough as children were less likely to have chronic cough symptoms, even after taking smoking history into account. There was no significant relation between whooping cough and early morning winter cough, asthma, or any other respiratory symptoms.

Roughly one fifth of the study children had been immunised against whooping cough by the age of 6 , but the effect of 
immunisation on the attack rate or severity of the disease cannot be estimated. Sixteen per cent of those immunised received the course of injections after having had whooping cough or in the same year as the attack. It was noted several times by the health visitor that children were immunised as a treatment for whooping cough at the beginning of an attack or in an attempt to shorten a protracted illness. This practice was not unknown, particularly in the first half of this century, ${ }^{14}$ but by 1949 it was no longer considered an effective treatment ${ }^{1 "}$; and in 1955 Spock wrote: "Whooping cough vaccine is sometimes given in severe cases but it has not been proved that it does much good." ${ }^{\prime \prime}$

\section{Conclusion}

The National Survey of Health and Development is an excellent study in which to investigate the long term consequences of whooping cough contracted at a time when immunisation was not widely available and when medical care for the condition was less effective than it is today. Thus we would have expected the consequences, if present, to have been more pronounced than in a more recent cohort. Despite the unexpected results found for the relation between whooping cough and chronic cough, however, there were in general no long term detrimental consequences of whooping cough as manifested by a reduced peak expiratory flow rate or respiratory symptoms at the age of 36 . This study is not suitable for investigating the neurological consequences of whooping cough because of their low prevalence, and for the same reason we could not exclude the possibility of long term respiratory deficit in the few most severely affected cases; nevertheless, from such evidence as was available this hypothesis was unlikely.

We could find no evidence that long term respiratory deficit associated with whooping cough was a factor which could play a part in the continuing controversy over the balance between risks associated with whooping cough and those associated with immunisation against it. The nub of the argument, therefore, still remains the need to protect young children from the risk of death or neurological damage from whooping cough weighed against the small but measurable risk of neurological illness associated with vaccination.

We thank Professor D L Miller and Dr J W B Douglas for their constructive comments on this work.

\section{References}

1 Fine PEM, Clarkson JD. Distribution of immunity to pertussis in the population of England and Wales. F Hyg (Camb) 1984;92:21-6.

2 James U, Brimblecombe FSW, Weston Wells $J$. The natural history of pulmonary collapse in childhood. Qf Med 1956;97:121-36.

3 Johnston IDA, Lambert HP, Anderson HR, Patel S. Respiratory morbidity and lung function after whooping cough. Lancet 1983;ii:1104-8.

4 Swansea Research Unit of the Royal College of General Practitioners. Respiratory sequelae of whooping cough. Br Med f 1985;290: 1937-40.

5 Atkins E, Cherry N, Douglas JWB, Kiernan KE, Wadsworth MEJ. The 1946 British birth cohort: an account of the origins, progess and results of the National Survey of Health and Development. In: Mednick SA, Baert AE, eds. Prospective longitudinal research: an empirical basis for the primary prevention of psychosocial disorders. Oxford: Oxford University Press, 1981:25-30.

6 MRC Committee on the Aetiology of Chronic Bronchitis. Standardised questionnaire on respiratory symptoms. Br Med f 1960;ii: 1665 .

7 Douglas JWB, Waller RE. Air pollution and respiratory infection in children. British fournal of Preventive and Social Medicine 1966;20:1-8.

8 Wetherill GB. Intermediate statistical methods. London: Chapman and Hall, 1981:130-56.

9 Nelder JA, Wedderburn RWM. Generalised linear models. Journal of the Royal Statistical Society A 1972:135:370-84

10 Cole TJ. Linear and proportional regression models in the prediction of ventilatory function. fournal of the Roval Statistical Society A 1975;138:297-338.

11 Johnston IDA, Hill M, Anderson HR, Lambert HP. Impact of whooping cough on patients and their families. Br Med F 1985;290:1636-8.

12 Colley JRT, Douglas JWB, Reid DD. Respiratory disease in young adults: influence of early childhood lower respiratory tract illness, social class, air pollution, and smoking. $\mathrm{Br} \mathrm{Med} \mathcal{J}$ 1973; iii: 195-8.

13 Kiernan KE, Colley JRT, Douglas JWB, Reid DD. Chronic cough in young adults in relation to smoking habits, childhood environment and chest illness. Respiration 1976;33:236-44.

14 Felton HM, Willard CY. Current status of prophylaxis by Hemophilus pertussis vaccine fAMA 1944;126:294-9.

15 Banks HS. Common infectious diseases. London: Edward Arnold, 1949:150.

16 Spock B. Baby and child care. London: Bodley Head, 1955:384.

(Accepted 2 December 1985)

\section{SHORT REPORTS}

\section{Hand infection with Mycobacterium chelonei}

I report on four patients with hand infection due to Mycobacterium chelonei after receiving steroid injections.

\section{Case reports}

A 72 year old woman (case 1) had complained of stiffness of both middle fingers for one year and had received multiple steroid injections to both fingers with only transient relief. Tender fusiform swellings had gradually developed. In Octobe 1983 an incisional biopsy was performed on the left middle finger. Chronic granulomatous tissues with acid fast bacilli were observed. The patient started treatment with streptomycin, isoniazid, rifampicin, and pyrazinamide, but her symptoms persisted, and the swelling and pain in the right middle finger worsened. She was admitted to hospital in December 1983.

On admission there was gross swelling over the proximal and middle phalanges of the right middle finger with extension of induration and erythema proximally to the metacarpophalangeal joint. A discharging wound was present over the radial aspect of the proximal interphalangeal joint. The left middle finger had swelling over the proximal interphalangeal joint only. The right middle finger was debrided, and extensive granulation tissues with necrosis of the extensor and flexor tendons were found. As the finger was beyond saving an open ray amputation was performed one week later. On culture $M$ chelonei grew, which was sensitive to kanamycin, amikacin, and doxycycline; partially sensitive to sulphamethoxazole; and resistant to streptomycin, isoniazid, and aminosalicylic acid. The patient started treatment with kanamycin. Four weeks later the wound was sutured, and the patient showed gradual improvement. Kanamycin treatment was stopped in April 1984

In August 1984 the patient presented again with recurrence of swelling in the left middle finger over the dorsum of the proximal interphalangeal joint. An excisional biopsy was performed that showed a fleshy granulomatous tissue over the extensor tendon. Culture again yielded $M$ chelonei. She was given amikacin and doxycycline. The wound healed, and chemotherapy was stopped after six weeks. On follow up in December 1984 there was no evidence of recurrence, and she could grip fully with both hands.

The table summarises the clinical details of three other patients with $M$ chelone infections. Initially, all patients had symptoms attributable to stenosing tenovaginitis, post-traumatic arthritis, or osteoarthritis. They were treated with steroid injections, and subsequently chronic swelling, pain, and stiffness developed. One patient (case 3) also had infection of the knee. In another patien (case 2) incision and drainage was performed: yellowish pus was drained, but on culture pyogenic organisms did not grow. Owing to the delay in diagnosis and treatment ray amputation was necessary in two patients. Recurrence of infection occurred in two patients requiring further debridement and chemotherapy. Two patients (cases 1 and 4 ) had received steroid injections from the same general practitioner. A contaminated water supply was subsequently identified in the clinic.

\section{Comment}

Although all four cases noted above occurred in Hong Kong, $M$ chelonei infection has been reported in England, ${ }^{1}$ the Netherlands, ${ }^{2}$ Sri Lanka, ${ }^{3}$ and the United States. ${ }^{45}$ It is an uncommon but potentially serious infection that can cause pulmonary disease, osteomyelitis, disseminated infection, and death. Mycobacteria should be considered when faced with an unusual infection.

$M$ chelonei, unlike most other mycobacteria, grows rapidly in culture (three to five days). The bacilli are pleomorphic, varying from cocci to slender forms and are usually present in scanty amounts. These characteristics contribute to the difficulty in identifying the organism on routine bacterial examination. The bacillus is resistant to most antituberculous 